\title{
De gode Muhammedanere: Den Danske Østerlandsmissions konstruktion af beduiner som muslimsk minoritet
}

\author{
af Daniel Henschen
}

\begin{abstract}
.
Den største danske organisation for islam-mission, Østerlandsmissionen i det nuværende Syrien (1898-1964), havde ved sin grundlæggelse beduin-stammerne i Qualamoun-distriktet nord for Damaskus som sit vigtigste indsatsområde. Disse stammer blev fremstillet som modstykke til den 'officielle' islam, som missionærerne anså for at være restriktiv og undertrykkende. Heroverfor stod beduinerne som indbegrebet af orientalsk moral og ædelhed. I praksis opgav de danske missionærer i løbet af få år at nå beduinerne. Men indtil da var beduinerne løbende genstand for en konceptualisering, hvor missionærerne forsøgte at forklare sig selv og støtterne hjemme i Danmark, hvorfor beduiner var det bedste missionsobjekt. Artiklen skildrer denne proces, der løb igennem den konsoliderende fase af Østerlandsmissionens historie, og der argumenteres for, at missionærernes erkendelsesproces kan ses som et - ganske vist på mange måder både fordomsfuldt og etnocentrisk - udtryk for en nuancering af et ellers meget monolitisk billede af islam. Derved skabtes et religiøst og kulturelt baseret koncept om 'minoriteter inden for islam' ud fra et praktisk behov i missionen.
\end{abstract}

Han kender saa godt Befolkningen i Ørkenbyerne [...] Han ved, at en Muhammedaner gerne vil sværge falsk Ed ved Retten, dersom han kan tjene en Pjaster derved. (Jensen 1916:96)

"Han" i citatet er beduinen Rarbân fra det nuværende Syrien. Forfatteren udtrykker holdningen til beduiner over for (andre) muslimer i den Danske Østerlandsmission, der i årene mellem 1898 og 1964 arbejdede for at udbrede kristendommen i Syrien og Palæstina. Artiklen her handler om denne konstruktion af beduinerne som en 'god' muslimsk minoritet. Dansk islam-mission er stort set ubehandlet som kilde til Danmarks forhold til den muslimske verden. Det lille hjørne, der gennemgås hér, er et foreløbigt resultat af de indledende studier til et større projekt om Østerlandsmissionens historie, men det skulle gerne antyde potentialet.

Østerlandsmissionen var 1900tallets største og mest betydningsfulde danske forsøg på at omvende muslimer og samtidig hovedkilden til viden om islam for flere tusinde danskere. De indledende år $\mathrm{i}$ Jerusalem var imidlertid præget af usikkerhed og skiftende fremtidsudsigter. Da missionen fra 1901 etablerede sig i det nuværende Syrien, var det med ét overordnet formål: Grundlæggeren Einar Prip og missionens støtter i Danmark ønskede at oprette en af de første kristne beduinmissioner. De overordnede hovedtræk i denne historie er behandlet mere eller mindre udførligt i de tre bøger, der findes om Østerlandsmissionens historie: Missionens egen officielle historie i form af bogen $\emptyset$ sterlandsmissionen er skrevet i 1923 af Chr. Siegumfeldt. Den tidlige periode er delvist behandlet af Bruno Bødker Hansen, der senere selv blev islammissionær, i bogen Blandt Muslimerne $i$ Kalamoun om årene frem til 1927 (Bødker Hansen 1987). Harald Nielsens bog Tålmodighed Forpligter (Nielsen 2005) fra Danmission rummer en udmærket, kort historisk redegørelse for 
Østerlandsmissionens samlede historie. Ud over det religiøse udgangspunkt er det fælles for alle værker, at de er skrevet ud fra den form, missionen fik efter sin konsolidering. Sådan at missionens begyndelse fremstår som et underordnet trin eller et vildskud på vejen. Det betyder, at de ganske vist omtaler strategien om at omvende beduiner men ikke går nærmere ind i præmisserne og den rolle, forestillingen om beduinerne spillede i Østerlandsmissionens ti første år. Det er denne 'beduin-fase' i Østerlandsmissionens historie, der danner grundlaget for de følgende sider. Under temaet muslim og minoritet undersøges den særlige rolle, de danske missionærer tildelte beduinerne som muslimsk minoritet - en rolle, der var en af forudsætningerne for at rodfæste missionen i Syrien.

Traditionen efter Edward Said giver ofte indtryk af, at Vestens strategiske vidensbehandling i den koloniale guldalder ikke var i stand til at opfatte samtidige nuancer mellem mellemøstlige grupper. Det eksisterer der en hel litteratur af indvendinger mod - mest indflydelsesrigt vel Robert Irwin (2007) og til dels Saids eget efterskrift til 1995-udgaven af Orientalisme (2002). Der findes intet tilsvarende missionshistorisk 'orientalismeværk'. Denne fremstilling fokuserer derimod på et konkret eksempel på behandlingen af en minoritet i islam, som den danske Østerlandsmission anså for væsentlig anderledes end majoriteten: Beduinerne. Hypotesen er, at idéen om beduinerne som opposition til mainstream-islam fik missionen til at fremstå som realistisk til trods for den ringe, generelle succes med islam-mission. Analysen bygger på trykte og utrykte kilder fra Østerlandsmissionen, dels rapporter og breve fra Østerlandsmissionens arkiv i Rigsarkivet, dels bøger og periodika. Den metodiske tilgang til behandlingen af beduinerne som minoritet ligger i forlængelse af en diskursanalytisk, Foucault-inspireret opfattelse af kategoriseringer som både redskaber for handling/magtudøvelse og de byggesten, der konstituerer verden - fordi objekter får deres værdi relationelt, uden at hverken relationer eller værdi er fastlagt én gang for alle (jvf. Foucault 1994:97ff.). Kernen i denne vedvarende proces er her, hvordan missionærerne så og anvendte beduinerne som en undergruppe af den samlede kategori 'muslimerne'. For at analysere behandlingen af dem som 'minoritet' er beretningerne om beduinerne derfor sat $\mathrm{i}$ forhold til beretningerne om andre muslimer samt den rolle, de spillede i Østerlandsmissionens arbejde. I første del af artiklen argumenteres for betydningen af beduinerne som muslimsk minoritet for Østerlandsmissionens opbygningsfase. I anden del analyseres de vigtigste enkeltelementer i missionærernes forestillinger om beduinerne som en særlig gruppe. Afslutningsvist opsummeres, hvordan Østerlandsmissionens religiøst og kulturelt baserede koncept om 'en minoritet inden for 
islam' svarede til et praktisk behov i missionen. Hovedvægten er lagt på perioden mellem 1898, hvor Østerlandsmissionen blev grundlagt, og 1905, hvor missionens overtagelse af den presbyterianske kirke i Qualamoun reelt betød, at driften af kirkens institutioner, skoler og hospital blev Østerlandsmissionens hovedaktivitet (Nielsen 2005:170-171).

\section{Beduinerne i Østerlandsmissionens historie}

Østerlandsmissionens grundlægger, præstesønnen Einar Prip fra Svendborg var allerede som barn grebet af tanken om at arbejde 'for evangeliet'. I 1891 fik han i følge egne oplysninger (Malmstrøm \& Munck 1938:9) et 'kald' om at omvende muslimerne. Efter i første omgang at være afvist af Dansk Missionsselskab fik han kontakt til det kristne børnehjem Syrisches Waisenhaus i Jerusalem, der garanterede ham en stilling som lærer. Kort efter etablerede Prip sammen med en gruppe grundtvigianere en forening, Østerlandsmissionens Venner, der skulle støtte hans planer om at drive selvstændig islammission. Allerede ved hans afrejse var der 33 støttekredse over hele Danmark - et tal der var fordoblet fïe år senere (Meddelelser fra Østerlandsmissionen 1902). I Prips første breve fra Jerusalem spores en frustration over kun at arbejde blandt kristne. Samtidig havde han vanskeligt ved at beslutte, hvor han skulle indlede det opsøgende arbejde blandt muslimerne, som var en del af aftalen med de danske støtter. Vendepunktet kom i 1898, og Einar Prip beskrev det sådan for formanden for Østerlandsmissionens Venner: "Men nu det som var Dagens Glanspunkt, og som var kilden til min overvættes Glæde. Om Formiddagen paa Vejen til Mar-Saba kom jeg for første Gang i Berøring med Beduiner." (Brev fra Einar Prip 11/5 1898). Intet i missionens tidligere forløb havde handlet om beduiner, men allerede et par dage efter mødet var Prip så grebet, at han fortsatte sit brev: "havde jeg nu kunnet tale med dem og til dem, hvor gerne var jeg da ikke blevet iblandt dem og blevet Beduinerne en Beduin, om jeg dog kunde vinde nogle." (ibid.). På hjemvejen bad Prip simpelthen til Gud, om "han vilde give mig den Naade at maatte tjene ham iblandt Beduinerne." (ibid.). De efterfølgende breve til formanden og støttekredsenes medlemsblad viser, hvordan beduinerne indgik i Prips initiativer for at grundlægge en selvstændig missionsbevægelse. I det følgende år opsøgte Prip informationer om beduiner, og fra en erfaren missionær fik han som råd at ansætte en lægemissionær; sammen ville de kunne rejse rundt med medicinsk hjælp til beduinlejrene og på den måde etablere den indledende kontakt (Brev fra Einar Prip 13/5 1899). Trods et tilbud om at erhverve en grund i Haifa til en ny missionsstation, rettede Prip sig mod Østjordan, dvs. det nuværende Syrien. Under et kortere ophold i Danmark i 1900 henvendte han sig til lægen Rudolf Fox Maule, og det aftaltes, at han tilsluttede sig missionen og fuldførte sin 
uddannelse i Mellemøsten. Fox Maule blev ansat ved et hospital i Damaskus, og støttekredsene i Danmark regnede tilsyneladende med, at det skulle være missionens base (Siegumfeldt 1923:84f). Prip havde imidlertid ændret holdning til den oprindelige tanke om en omrejsende mission. Allerede ved sin anden afrejse meddelte han $\mathrm{i}$ en tale til missionens venner, at en lægemission krævede, at missionærerne havde en fast menighed, hvis de skulle tolereres af de osmanniske myndigheder (Meddelelser fra Østerlandsmissionen, 1901:11). Som et skridt i den retning skaffede Fox Maule kontakt til The Presbyterian Church in Ireland, som siden 1860 havde ledet en række små protestantiske menigheder i Qualamoun-distriktet nord for Damaskus. Som noget enestående havde irerne tilladelse til at undervise børn af alle trosretninger - også muslimer -, og Prip så muligheder i Karyatén, den fjerneste af de landsbyer, hvor de irske missionærer havde missionsstationer: "Mange Beduiner, tænker jeg, vilde man dér komme i Berøring med og maaske bosiddende Beduiner, iblandt hvilke et missionsarbejde vilde falde betydelig lettere." (Brev fra Prip 22/7 1902). Som en begyndelse flyttede Prip i en toårig periode til Karyatén, hvor han boede hos den lokale presbyterianske lærer. Den irske mission ønskede imidlertid, at danskerne overtog hele den skrantende mission i Qualamoun. Det indebar driften af en række skoler og kirker samt andet administrativt arbejde blandt folk, der i forvejen var kristne. Året efter skrev Fox Maule til de $\varnothing$ konomiske støtter i Danmark og forsikrede dem om at: "Alle de Stationer i de Egne er rigeligt omgivne af Beduiner, og det vil aldrig gaa os af sinde, at det er til Muhammedanerne, vi er sendte." (Særlige Meddelelser fra Østerlandsmissionen, 1903, nr. 7). Det virker næsten, som om Fox Maule allerede havde en fornemmelse af, hvad deres arbejde reelt ville gå med, da han samtidig på forhånd indskrænkede den oprindelige målsætning til en mere sæsonbetonet opgave: "Det er da vor Hensigt at [...] gøre særlige Beduinture hvert Aar" (ibid.). Overtagelsen af missionsstationerne i Qualamoun fandt sted i 1905. Missionærerne forsøgte herefter opsøgende arbejde blandt beduinerne, og allerede, mens Einar Prip boede i Karyatén så det kortvarigt ud til, at arbejdet skulle bære frugt: Beduinen Kabban opsøgte Prip og meddeler, at han ønskede at døbes. I det næste år indtil Kabbans død af tuberkulose svævede Prip og til dels Fox Maule i en lykkerus: "For hver Dag fik jeg ham kærere [...] Og Gud knyttede et Baand imellem os, som jeg tror og haaber skal vare i Evigheden" (brev fra Einar Prip 1903).

Efter Kabbans død kom beduinmissionen gradvis til at stå i skyggen af institutionsarbejdet og arbejdet i de kristne menigheder - især efter grundlæggelsen af et hospital, der voksede frem af den oprindelige tanke om lægehjælp til beduinerne, men det fremgår af missionens statistik, at der var 
meget få beduiner blandt patienterne (Meddelelser fra Østerlandsmissionen 1910). Beduinerne optrådte stadig i brevene til Danmark, og mange af missionærerne ankommer stadig med ønsket om at arbejde for at "nogle af disse vore brune Ørkensønner vilde give deres Hjærte til Jesus" (Brev fra Johanne Svanenskjold 31/7 1902). Men de 11 danske missionærer, der i 1914 befandt sig i Syrien, havde stor set alle faglige kompetencer - fx som læger og sygeplejersker -, der rettede sig imod institutionerne frem for det opsøgende arbejde, som var den eneste kontinuerlige kontaktflade med beduiner. En delvis undtagelse er sygeplejersken Kirsten Lauritsens planer fra 1909 om en teltmission, der skulle følge med beduinerne og sørge for læge- og hospitalshjælp. Det projekt gik imidlertid i sig selv, efterhånden som også Lauritsen kastede sig over den kristne bybefolkning (Bødker Hansen 1987:93).

\section{Hvordan adskilte beduinerne sig?}

I de tidligere bøger om Prips opdagelse af beduinerne fremstår dét som lidt af et tilfælde. Hvis man nærlæser Prips breve hjem, indeholder de imidlertid et bud på et svar i form af en generel vilje til at opsøge andre grupper end den sunni-muslimske majoritetsbefolkning. Året efter mødet med beduinerne skrev Prip således om et møde med et drusersamfund, som optog ham meget; "og jeg bad Gud om, hvis det var et vink, da at føre mig videre og lede mig med mine Øjne" (Brev fra Einar Prip 13/5 1899). I et stykke tid stod Prip faktisk og vaklede mellem begge grupper men valgte altså til sidst sin første interesse, beduinerne. Både Prip og Østerlandsmissionens Venner vidste, at beduinerne var muslimer, men som også Harald Nielsen har bemærket, foretog Prip en ændring i fokus ved at orientere sig mod 'beduiner', mens støtterne i Danmark talte om 'muslimer' (Nielsen 2005:159). Det er denne divergens, der tegner omridset af beduinerne som minoritet; dvs. de markører som Østerlandsmissionen satte på beduinerne som adskillelse fra majoriteten. Det giver samtidig et bud på, hvorfor beduinerne blev anset for at være en mere 'missionsegnet' minoritet. Når ingen af de tidligere værker beskæftiger sig med dét spørgsmål, skyldes det muligvis, at Østerlandsmissionens beskrivelser af beduinerne er subjektive meningstilkendegivelser, der kun i meget ringe grad har til hensigt at beskrive den lokale kultur. Det gør imidlertid ikke værdien af dem mindre, hvis målet er at forstå processen fra missionærernes side. Kort sagt, dét at beduinerne adskilles fra de $\emptyset$ vrige muslimer på tre områder, der netop interesserede missionærerne: I kraft af deres moral, deres tilgang til missionen og deres holdning til islam: 
1. Moral: AErlig over for uarlighed. I denne artikels indledende citat udtaler en beduin sig om det hykleri og den amoral, han ser hos sine muslimske - og i det fuldstændige citat også kristne naboer. Det er karakteristisk, at uanset hvor negativt beduinerne omtales i sammenhænge, hvor de støder sammen med bybefolkningen, så er de - som i det nævnte citat - moralsk overlegne. Især er ærlighed et af de træk, der vendes tilbage til i Prips breve om beduinen Kabban. Kabban har fx boet hos en muslimsk familie, hvor "De lyver og bander og taler onde Ting hele Dagen" (Kabban 1910:13). Men alligevel må Prip konstatere, at den unge beduin er "bleven bevaret forunderlig ufordærvet i de Omgivelser, han har levet i" (ibid.). I brevene om Abdallah, en sunni-muslim, som viste interesse for missionen, er mistro og løgn omvendt et tilbagevendende tema (Prip 1946). At det ikke kun handler om individuelle træk ses af et af Prips første breve om beduinerne: "Det er en ganske anderledes ædel og ærlig og venlig Race end Fellahaerne (den muhammedanske Landbefolkning)" (Brev fra Einar Prip 11/5 1898). De arabiske samfund blev i det hele taget set som noget, der fordærver: "[D]e er børn af et letsindigt, letbevægeligt af Regeringen udsuget, forarmet folk, der hutler sig igennem" (Brev fra Einar Prip 21/4 1898). Over for det stod beduinerne som indbegrebet af en oprindelig og bedre Orient med bibelske rødder; de var, som det hed, "skikket at føre os ind i Kedars Telte" (Brev fra Einar Prip 25/6 1903) med et citat fra Højsangens omtale af фrkennomader (Biblen 1992, kap 1, vers 5). På den måde pegede missionærerne på det moralske 'materiale', der i missionens forestillinger skulle være til stede for at muliggøre konversion til kristendommen. Det ses tydeligst ved at sammenligne med den måde, de arabiske kristne på baggrund af deres manglende moral frakendes deres status som kristne: "Det er børn af kristne arabere, saakaldt kristne. Thi i reglen er forskellen mellem dem og de muhammedanske Brødre lig i moralsk henseende" (Brev fra Einar Prip 21/4 1898).

\section{Mфde med missionen: Nysgerrig over for fanatisk indskranket}

En af de første kvaliteter ved beduinerne, der omtales, er deres angivelige lydhørhed og nysgerrighed over for kristendommen. Beskrivelserne af den фvrige befolkning handler tit om missionærernes klare og muslimernes svage argumenter, når de gensidig prøver at overbevise hinanden. Beskrivelser af beduiner er derimod ofte bygget op om temaerne undren og spørgsmål: "Han er for Øjeblikket alene i Teltet, han har jaget de andre ud; thi han grunder over en mærkelig Oplevelse" (Jensen 1916:95). Det skal ses i lyset af, at konvertitternes personlige motivation var

missionens suverænt vigtigste ideologiske princip. ${ }^{8}$ Som iboende kvaliteter tjente nysgerrighed, velvillighed og åbenhed til at adskille beduinerne fra andre muslimer. I brevene om beduinen 
Kabban understreges det således, at det er de omgivende byboere, som vil hævne hans eventuelle dåb og ikke hans 'stammefæller'; de er tværtimod taknemmelige for, at Prip har taget sig af ham (Kabban 1910:61). Muslimer generelt beskrives ret konsekvent som bedrevidende og selvhøjtidelige; de $\varnothing$ nsker simpelthen ikke at høre Ordet; den første forudsætning for mission. Et karakteristisk eksempel, der næsten ordret optræder flere steder, er følgende beskrivelse af en af de situationer, hvor det trods alt lykkedes at få muslimer i tale: "Han blev saa vitterlig kørt fast [af Prips argumenter for kristendommen] at han slet ikke kunne svare [...] han blev derfor fornærmet og vred og vilde ikke lukke sin Mund op mere" (Brev fra Einar Prip, 19/1 1905). Som et tilbagevendende tema $\mathrm{i}$ hele Østerlandsmissionens historie tydeliggøres forestillingen om den fanatiske muslim gennem det potentiale, Østerlandsmissionen forlenede beduinerne med. Så meget mere som det var noget, selv den kristne befolkning manglede i missionærernes optik. Om den eneste anden beduin, som Østerlandsmissionen kom i nærmere kontakt med, ud over Kabban, skriver Harald Nielsen: "de tilstedeværende kristne forstyrrede deres samtale og gjorde tykt nar af denne nomade, der ville vide noget om deres tro" (Nielsen 2005:174).

\section{Viden/ideologi: ikke-kendskab til islam over for kendskab}

I 1901, efter at han reelt havde taget beslutningen om beduinmission, spurgte Prip en erfaren missionær om særlig gode steder at missionere. Han gengav selv svaret sådan: "Blandt Beduinerne! Blandt Beduinerne [...] Beduinerne kende ikke deres egen Religion og ere [...] modtagelige for Evangeliet." (Brev fra Einar Prip, feb. 1901). Dette syn går igen i de følgende beskrivelser og bygger som de andre 'beduin-markører' på forestillingen om den halvvilde beduin, der lever tættere på naturen og ikke er fordærvet af civilisationen. Alligevel skyldes det ikke kun en forestilling om, at 'jo mindre anden religion, jo mere plads til kristendom', at det manglende kendskab til islam blev tillagt central betydning. Som i de ovenstående eksempler kommer man forklaringen nærmere ved at se, hvordan denne karakteristik samtidig er en karakteristik af, hvad missionærerne anså for at være normen i islam: Den gang som nu blev islam ofte fremstillet som en monolitisk lovreligion, der bestemte over enhver del af de troendes liv (Bæk Simonsen 2004:159-161). Emblematisk udtrykt i titlen på en af de mest populære danske bøger om islam-mission, der ganske vist først udkom 1921: Muhammeds Aag (Clausen 1921). Sat på spidsen mente missionærerne, at islam som system havde en kvalitet, der i sig selv hindrede dens medlemmer i at konvertere. Derfra er der ikke langt til at antage, at konversion måtte være lettere hos dem, der i forvejen besad begrænset kendskab til deres 'egen' religion - dvs. dem, der var længst fra 'systemet islam'. Med beduinerne 
havde missionærerne i egen forståelse at gøre med ufordærvede individer, som fordomsfrist kunne sætte sig ind i begge religioner og veje dem imod hinanden - underforstået til kristendommens fordel. Denne stillingtagen skal ikke undervurderes; den ovennævnte grundtanke i protestantisk mission om den personlige motivation, som krævede, at konvertitten vidste, hvad han gik ind til, vedrørte nemlig både tidligere og kommende religion. I tilfældet Kabban udskød Prip og Fox Maule således hans dåb, fordi de var bange for, at han endnu ikke havde den viden, der var nødvendig for at tage stilling til kristendommen: "Derfor skal Du selv veje og prøve Evangeliet og Koranen, Jesus og Muhammed" (Kabban 1910:11). I det følgende afsnit, vil jeg diskutere, hvordan denne skelnen mellem islam forstået som undertrykkende system og muslimerne som ofre for denne, var baseret på missionens manglende succes.

\section{Praktiske minoriteter - at opdele verden med et formål}

Til verdenskonferencen for missionærer i Edinburgh 1910 sendte Østerlandsmissionen følgende meddelelse: "No field of work where work is possible must be neglected therefore neither the most difficult of all viz among the Turkish Mahometans" (Østerlandsmissionens arkiv). Det er en selvbevidst kommentar, der samtidig rummer et element af frustration over fremtidsudsigterne. Jeg mener, man skal se ovennævnte fremstillinger af beduinerne i dét lys. Det kan virke naturligt, at missionærer fremstiller dem, de ønsker at omvende, som de absolut bedst egnede. Billedet af beduinerne virker da også umiddelbart som udelukkende en samling letkøbte orientalistiske fordomme og klichéer - svarende til samtidens populære billede af Mellemøsten. Det er dog kun til en vis grad: Flere studier har peget på betydningen af klassificeringssystemer, taksonomier, for etableringen af den imperialistiske æras transnationale strukturer; som en mekanisme, hvor andre grupper reduceres til at få deres mening relationelt som 'indfødte', 'sekter', 'lavkaste' osv. som udstrålinger fra kolonisatorens handlinger og vidensregimer (jvf. Chakrabarty 2000:33). På samme måde mener jeg, de tre ovenstående sider af missionærernes beduinstereotyp skal forstås; som en 'missionstaktisk' konstruktion af en islamisk minoritet, der faktisk kan konverteres. Dvs. at beduininteressen og -missionen som Østerlandsmissionens første raisson d'etre tjente et strategisk formål. Og at den ophørte, bl.a. fordi missionærerne med institutionsdriften havde fået et andet projekt at kaste sig over; dvs. at udleve deres kald igennem. Som det ses, indeholder fremstillingen af beduinerne både en beskrivelse af vanskelighederne ved islammission og af mulighederne for at konvertere en enkelt muslimsk gruppe. De orientalistiske klichéer i beduinbeskrivelserne tjener altså et taktisk formål. Jeg betvivler ikke, at missionærerne oprigtig har 'villet' beduinerne, men 
vilkårene og synet på islam som sådan formede den måde, de blev konstrueret på. Det betyder, at noget, der bl.a. har rod i en romantisk essentialisering af en gruppe, faktisk kommer til at åbne for en differentiering inden for samme gruppe. Missionærerne begyndte at interessere sig for, at der eksisterer forskellige udtryk for islam. At grundlaget for denne differentiering ikke nødvendigvis holder for en antropologisk efterprøvning, er en anden sag. Østerlandsmissionens baggrund er den imperiale fase, hvor Vesten i følge Edward Said hovedsagelig anskuede Orienten gennem "et sæt strukturer, man havde arvet fra fortiden" (Said 2004:152). Eksemplet Østerlandsmissionen og beduinerne står ikke i modsætning til Saids konklusioner. Men det viser, hvordan der også lå et produktivt potentiale i fordommene, netop fordi de præsenterede en forståelse af det ukendte, som missionærerne kunne agere inden for. De kunne kort sagt appliceres på bestemte grupper for at adskille dem fra andre, hvilket skaber basis for missionærernes egne iagttagelser. Denne undersøgelse slutter her, men næste generation af missionærer i Østerlandsmissionen gik faktisk i gang med at studere de enkelte grupper i deres tidslige og etniske kontekst. I 1920erne med udgangspunkt i en læsestue i Damaskus og gennem fælles bogprojekter mellem missionæren Alfred Nielsen og muslimske teologer, samt ved at missionen betalte syriske prædikanters ophold ved det vigtigste islamiske universitet, Al-Azhar i Kairo, hvor de kunne lære islam at kende. Det er i sig selv en lille historie, men Østerlandsmissionens betydning og relationer gør det formentlig til en central hændelse i Danmarks relation med den muslimske verden. I årene fra første verdenskrig og frem til 1950erne fik Østerlandsmissionen støtte fra flere tusind enkeltpersoner i Danmark. Det gjorde missionen nærværende $\mathrm{i}$ en dansk virkelighed gennem aktiviteter, der spændte fra køb af særlige produkter (hvoraf missionen modtog en vis procentdel), over basarer med 'arabisk kunst', til studiekredse (som i mellemkrigsårene let kunne få 100 københavnere til at mødes hver uge). For alle disse mennesker var beretningerne om muslimer kontra beduiner med til at forme forestillingerne om islam.

\section{Upubliceret kildemateriale i Østerlandsmissionens arkiv i Rigsarkivet, Arkivnr. 10065}

Til Østerlandsmissionens Kredse, hektograferet nyhedsbrev 1898-1900.

Særlige meddelelser fra Østerlandsmissionen, hektograferet nyhedsbrev 1902-1906.

Breve fra Einar Prip 1898-1914.

Breve fra Johanne Svanenskjold 1902-1914.

Div. rapporter og meddelelser. 


\section{Litteratur}

Bibelen, 1992: Det Danske Bibelselskab, København.

Bæk Simonsen, Jørgen, 2004: Islam med danske фjne: danskeres syn på islam gennem 1000 år, Akademisk forlag, København.

Bødker Hansen, Bruno, 1987: Blandt muslimerne $i$ Kalamun: Østerlandsmissionens arbejde $i$ Syrien indtil 1927, Gad, København.

Chakrabarty, Dipesh, 2000: Provincializing Europe: Postcolonial Thought and Historical Difference, Princeton University Press, Princeton.

Clausen, Agnes, 1921: Muhammeds Aag, København.

Foucault, Michel, 1994: Viljen til viden, Seksualitetens historie 1, Det lille Forlag, Frederiksberg Irwin, Robert, 2007: Af begar efter viden: orientalisterne og deres fjender, Vandkunsten, København.

Jensen, Jensine, 1916: Billeder fra Østerland, O. Lohse.

Kabban (uden redaktør), 1910: Østerlandsmissionens Smaaskrifter.

Lévi-Strauss, Claude, 1994: Den vilde tanke, Gyldendal, København.

Malmstrøm, Johs. \& Munck, Ferd., 1938: Østerlandsmissionen gennem 40 Aar: missioncerernes skildringer fra arbejdsmarken før og $n u$, Lohse.

Meddelelser fra Østerlandsmissionen, Østerlandsmissionen, tidsskrift 1901-1921.

Nielsen, Harald, 2005: Tålmodighed forpligter: 9 kapitler af Danmissions islamhistorie, Unitas, Frederiksberg.

Prip, Einar, 1946: Breve fra Einar Prip, J. Frimodts Boghandel, København.

Said, Edward W, 2004: Orientalisme: Vestlige forestillinger om Orienten, Roskilde Universitetsforlag, Frederiksberg.

Siegumfeldt, Christian, 1923: Østerlandsmissionen: historisk skildret, bd. 1, Lohse.

\footnotetext{
${ }^{8}$ Dette kan virke paradoksalt, når man tænker på det enorme apparat, der blev sat i værk for at opsøge og overbevise andre mennesker. Missionærerne frygtede da også, at de ikke-kristne enkeltpersoner, der måtte opsøge dem kom af andre - især økonomiske - årsager.
} 
Daniel Henschen (f. 1980), cand. mag., er ansat ved Center for Kultur og Udvikling i København. Han har forsket i religiøse udviklingsorganisationers historie, senest med artiklen "Kald og udviklingsbistand i det uafhængige Indien: Postkolonial selvforståelse i to skandinaviske missioners institutionsarbejde" i (Svensk) Historisk tidskrift, 2010 (nr. 1). Med støtte fra Det Danske Institut i Damaskus foretog Daniel Henschen i 2009 et feltstudie i 'Syrien efter arven fra Østerlandsmissionen'.

\section{English résumé}

Østerlandsmissionen - 'The Danish Oriental Mission' - is the most significant Danish organisation working for Muslim conversion to Christianity and was based in current Syria (18981964). Initially the organisation's main priority was the Bedouin tribes in the Qualamoun district north of Damascus. These tribes were constructed as a counterpart to the 'official' Islam, considered by the missionaries to be restrictive and oppressive. The Bedouins were regarded as the epitome of oriental morality and nobility. The Danish missionaries were forced to relinquish their attempts to reach the Bedouins after a few years. But prior to this, the Bedouins were subjects of an ongoing conceptualisation in which the missionaries attempted to justify their existence, support from Denmark and the Bedouins as the mission's target group. This article describes the process that ran through the consolidation phase of Østerlandsmissionen's history. It argues that the missionary process of cognition can be viewed as a process - admittedly in many ways both biased and ethnocentric - adding perspectives to an otherwise monolithic image of Islam. Thereby, a religiously and culturally based concept of 'minorities within Islam' was created from the functional existence of the mission. 